\title{
Gingival Health in Patients Treated with Full Veneer Crown Restorations in Al-Riyadh Province, Kingdom of Saudi Arabia
}

\author{
Fawaz Alqahtani ${ }^{1}$, Ahmed Algohar ${ }^{2}$, Abdulrahman Alhazzaa $^{3}$, Amir Dimashkieh $^{4}$
}

\begin{abstract}
Aim: The aim of this study was to assess the effect of different marginal locations and fabrication places on the gingival health of patients treated with full veneer crown restorations, at Al-Riyadh province, Kingdom of Saudi Arabia.

Materials and methods: A cross-sectional study was performed to assess the gingival health of patients with full veneer crown restorations. Thirty-nine patients with 45 full veneer crowns have been examined in two places: College of Dentistry (Prince Sattam Bin Abdulaziz University) and East Riyadh Specialist Dental Center; both places are in Al-Riyadh province, Kingdom of Saudi Arabia. The gingival index by Loe and Sillness has been used to assess gingival health. Patients have been examined from December 2016 to March 2017.

Results: A tooth restored with full veneer crowns showed a high gingival index (1.10) than the contralateral unrestored tooth in the same patients. There were significant differences between subgingival margin (1.14), supragingival (0.69), and equigingival (0.73) margin on gingival health. There were significant differences between full veneer crowns fabricated at government clinics $(0.81)$ and full veneer crowns fabricated at private clinics (1.10) on gingival health. There were no significant differences on gingival health between patients with different educational levels.

Conclusion: Subgingival margin of full veneer crowns has a higher gingival index than the equigingival and supragingival margin. Full veneer crowns fabricated at governmental clinics have a lower gingival index compared with full veneer crowns fabricated at private clinics, with no positive relationship between the educational level and gingival health around the crown.

Clinical significance: The location of the finish line as well as the fabrication place will significantly impact the gingival health of the final full veneer restorations.

Keywords: Crowns, Fabrication place, Full veneer crown, Gingival health, Gingival index, Gingival margins.

World Journal of Dentistry (2019): 10.5005/jp-journals-10015-1643
\end{abstract}

\section{INTRODUCTION}

Full veneer crowns have been the main type of restoration used in fixed prosthodontics in recent decades, as they serve as an excellent means to protect a weakened tooth structure and to improve esthetics and restore tooth function. ${ }^{1}$ Many factors influencing the long-term biological success of the full veneer crowns such as the location of crown margin, ${ }^{2}$ marginal adaptation, ${ }^{3}$ materials, and the contour of the crown. ${ }^{4}$

There are three types of crown margin locations: supragingival, equigingival, and subgingival margin. The subgingival margin location is indicated in certain cases such as short clinical crown, improve esthetic, and subgingival caries. Generally, the margin of the crown should be placed in an area where it can be easily finished by the dentist and kept clean by the patient. ${ }^{5}$ Many studies have been conducted to assess the effect of margin location to gingival and periodontal health. A histological study by Karlsen ${ }^{6}$ showed that the best location of crown margin is supragingival when compared with equigingival and subgingivallocations. Many clinical studies showed that the subgingival crown margin is more likely to cause gingival inflammation than equigingival and supragingival margin, as in a study done on 78 Saudi patients to evaluate the effect of fixed partial dentures on the periodontal status of abutment teeth, and 76 patients showed an increase in gingival index scores more than nonabutment teeth. ${ }^{7}$ Aboelsaad et al. ${ }^{8}$ have checked the effect of crown margin location and materials on periodontal health over 100 patients, and found that crowns with supragingival margins are better on periodontal health than crowns with subgingival
1,2Department of Prosthodontics, College of Dentistry, Prince Sattam Bin Abdulaziz University School of Dentistry, Al-Kharj, Kingdom of Saudi Arabia

${ }^{3}$ Dental Division, Ministry of Health, Al-Kharj, Kingdom of Saudi Arabia ${ }^{4}$ Department of Prosthodontics, College of Dentistry, Dar Al Uloom University School of Dentistry, Al-Kharj, Kingdom of Saudi Arabia

Corresponding Author: Fawaz Alqahtani, Department of Prosthodontics, College of Dentistry, Prince Sattam Bin Abdulaziz University School of Dentistry, Al-Kharj, Kingdom of Saudi Arabia, e-mail: implantologist@yahoo.com

How to cite this article: Alqahtani F, Algohar A, Alhazzaa A, et al. Gingival Health in Patients Treated with Full Veneer Crown Restorations, in Al-Riyadh Province, Kingdom of Saudi Arabia. World J Dent 2019;10(4):280-284.

Source of support: Nil

Conflict of interest: None

margins. Another study done on 423 patients (68 patients with supragingival margins; 355 patients with subgingival margins) to see the relationship of the position of crown margins to gingival health, gingival bleeding and gingivitis can be observed on subgingival margins more than supragingival margins. ${ }^{9}$ Silness ${ }^{10}$ examined over 385 abutment teeth and 385 controlled teeth to check the periodontal conditions in patients treated with dental bridges, and found that abutment teeth show increase on gingival index more than nonabutment teeth, and the severity was most pronounced 
on subgingival margins. Valderhaug et al. ${ }^{11}$ also examined 102 patients to evaluate oral hygiene, periodontal conditions, and carious lesions in patients treated with dental bridges, and found that gingival index increased and the scores were higher when the crown margins was located subgingivally. Valderhaug ${ }^{2}$ did another study in 1976 on 114 patients to evaluate the periodontal conditions in patients 5 years following insertion of fixed prostheses; gingival health improved when the margins located supragingival or at the level of gingival, where the gingival index scores increase with subgingival. Reitemeier et al. ${ }^{12}$ did a study on 240 patients with 480 metal-ceramic crowns to evaluate the effect of posterior crown margin placement on gingival health, and concluded that the gingival margin is one of several parameters that will affect the gingival health.

Patients with full veneer crowns should be instructed to use oral hygiene aids in the appropriate way and to use supplementary cleaning instruments, which allow a more effective removal of dental plaque. ${ }^{13}$ In addition, they need a periodic recall to maintain an excellent health of the periodontium. Studies demonstrated that frequent careful cleaning of teeth by the patients with full veneer crown helps maintain good gingival health. ${ }^{13,14}$

Most of the studies were done in different countries and were focusing on the relation between gingival marginal location and health of the gingiva regardless of the eductional level of the patients and fabrication place of the crown. Therefore, the aim of this study was to assess the effect of different marginal locations and fabrication place (governmental or private clinic) on gingival health of full veneer crowns. The null hypothesis is that the marginal locations and the fabrication places will not affect the gingival health of the full veneer crown restorations.

\section{Materials and Methods}

A cross-sectional study was conducted to assess the gingival health of patients with full veneer crowns. The patients have been examined in two places: College of Dentistry (Prince Sattam Bin Abdulaziz University) and East Riyadh Specialist Dental Center, in Al-Riyadh province, Kingdom of Saudi Arabia.

Patients had been examined from December 2016 to March 2017. The exclusion criteria were those patients with one of the following: fixed partial denture, fixed orthodontic appliances, patients without prosthetic restorations, patients with systemic diseases that affect the periodontal health (e.g. diabetic patients), patient on drugs that lead to gingival hyperplasia (e.g. contraceptive pills), and pregnant women. An estimated 39 patients with 45 full veneer crowns were included in this study; 6 of them have two single crowns. Patients were aged between 17 years and 75 years, whereas 19 of them are males and 21 are females. The marginal locations were determined and subgingival margins considered when the margin was $0.5-1 \mathrm{~mm}$ below the free gingival margin. ${ }^{15}$

Teeth restored with full veneer crowns were probed and reading was taken at four points (distal facial papilla, midfacial margin, mesial facial papilla, and midlingual margin) to assess the gingival health using the gingival index (Table 1). ${ }^{16}$ The periodontal probe is introduced in the sulcus until resistance has met; at that point, reading was taken. In the same way, reading has taken to the contralateral unrestored tooth, which is considered as a control. One clinician who has been trained by an experienced periodontist did all measurements.
Table 1: Gingival index scores

\begin{tabular}{ll}
\hline Score/value & Gingival index \\
\hline 0 & No inflammation \\
1 & Mild inflammation, no bleeding elicited on \\
& probing \\
3 & Moderate inflammation, bleeding on probing \\
\hline
\end{tabular}

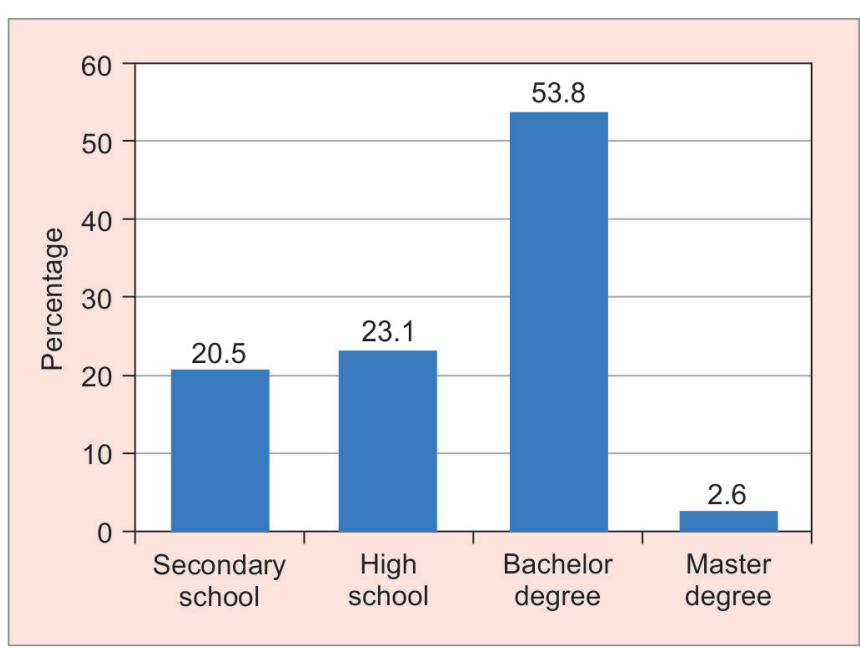

Fig. 1: Distribution of full veneer crowns by the educational level

\section{Results}

An estimated 45 full veneer crowns were included in this study from 39 patients, 18 (46\%) males and 21 (54\%) females. The mean $( \pm S D)$ age of the patients was $36.03 \pm 13.40$ years, ranging from 17 to 75 years. All patients had full veneer single crowns with a mean longevity $( \pm S D)$ of 3.41 ( \pm 3.52 ) years, ranging from 3 months to 20 years. A majority of patients $(59 \%, n=23)$ use oral hygiene aid and brush twice a day. The majority of patients with full veneer crowns had a bachelor's degree $(53.8 \%, n=21)$ (Fig. 1).

\section{Margin Placement and Fabrication Place}

Thirty-five patients (64\%) had subgingival margin placement for full veneer crowns (Fig. 2). 61\% of fabrication places for full veneer crowns were in private clinics (Fig. 3).

\section{Gingival Index}

Table 2 shows that the mean $( \pm S D)$ gingival index score and the mean interpretation score were 0.99 and 0.90 , respectively. The area with full veneer crowns showed a mean $( \pm S D)$ gingival index score of $1.10( \pm 0.40)$ and the area without full veneer crowns showed 0.94 $( \pm 0.55)$; so the teeth with crowns have a higher mean gingival index than teeth without crowns, and all the crowns in this study have an effect on the health of the gingival, where the teeth without crowns have lower gingival scores.

A one-way analysis of variance and an independent sample $t$ test showed a statistically significant difference in the gingival index with fabrication place and margin placement $(p<0.05)$.

Government clinics have lower gingival index scores than private clinics (Table 3 ). No significant difference is observed on gender or educational level. The higher gingival index scores of crown margins in this study are noted for subgingival margin (1.14), while the supragingival have the lower gingival index scores (0.69). 


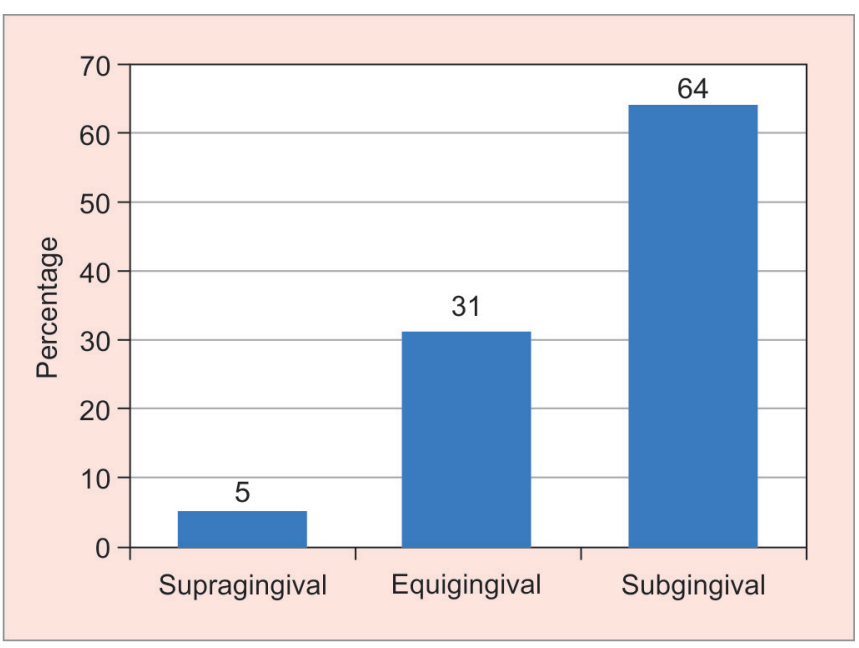

Fig. 2: Types of full veneer crowns by margin placement

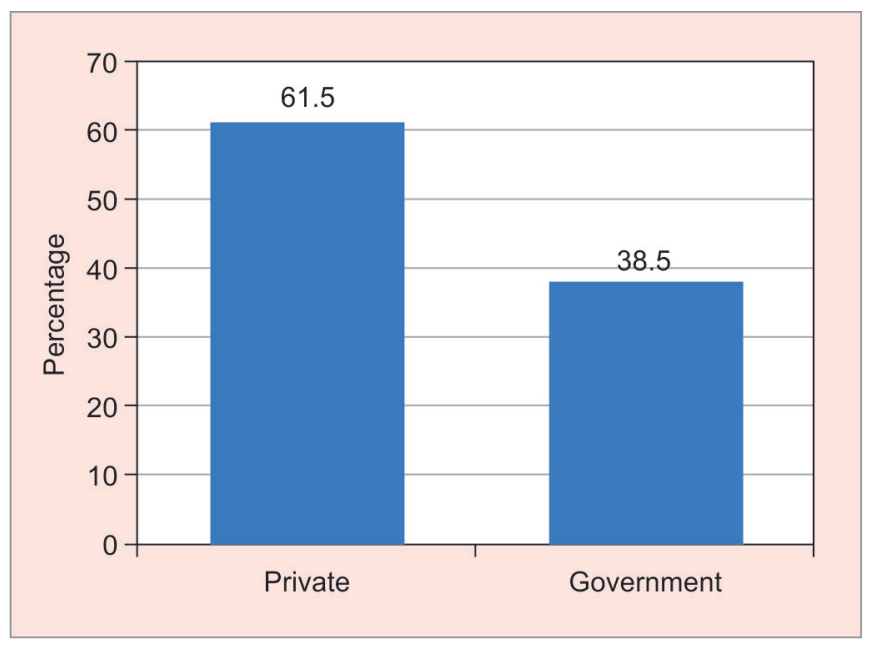

Fig. 3: Distribution of full veneer crown fabrication place

Table 2: Mean $( \pm S D)$ gingival index score

\begin{tabular}{lllll}
\hline & Mean & $\begin{array}{l}\text { Standard } \\
\text { deviation }\end{array}$ & Minimum & Maximum \\
\hline Area with full veneer crowns & 1.10 & 0.40 & 0.00 & 2.00 \\
Area without full veneer crowns & 0.94 & 0.55 & 0.00 & 2.00 \\
Interpretation & 0.99 & 0.39 & 0.44 & 2.00 \\
\hline
\end{tabular}

Table 3: Comparison of gingival index

\begin{tabular}{lllll}
\hline \multirow{2}{*}{ Variable } & & Mean & $\begin{array}{l}\text { Standard } \\
\text { deviation }\end{array}$ & p value \\
\hline Gender & Male & 0.98 & 0.39 & 0.847 \\
Fabrication place & Female & 1.00 & 0.40 & \\
Educational level & Private & 1.10 & 0.38 & 0.023 \\
& Government & 0.81 & 0.35 & \\
& Secondary school & 1.07 & 0.39 & 0.099 \\
& High school & 1.22 & 0.44 & \\
Margin placement & Bachelor degree & 0.87 & 0.33 & \\
& Master degree & 0.69 & - & \\
& Supragingival & 0.69 & 0.85 & 0.004 \\
& Equigingival & 0.73 & 0.19 & \\
\hline
\end{tabular}

\section{Discussion}

The null hypothesis that educational level of the patients and the fabrication place of the full veneer crown had no influence on the gingival health around full veneer crown has been rejected.

Gingival health around full veneer crowns that have been fabricated at government clinics showed a better response than full veneer crowns fabricated at private clinics. Gingival tissue can bleed easily and the swelling are more obvious; if the warning signs are ignored or not treated, gingivitis can simply progress to periodontitis, which then definitely leads to teeth loss. ${ }^{17}$ Orkin et al. ${ }^{9}$ supported that subgingival margins had a greater chance of gingival bleeding and gingival recession than supragingival margins. Full veneer crown should be properly contoured and following the original tooth anatomy to maintain and preserve the surrounding gingival tissue. Over contoured full veneer crowns are considered as a contributing factor in the etiology of the periodontal disease. ${ }^{18}$ Also Sackett and Gildenhuys ${ }^{19}$ found that there is a relationship between the full veneer crown over contouring and the gingival tissue inflammation. In the area where the esthetic considerations decreased or not critical, flattening of the full veneer crown is preferred and accepted so as to reduce the chance of getting a gingival tissue inflammation. ${ }^{20}$ The marginal location of the full veneer crowns may affect the gingival tissue health; this can occur by increasing the possibility for the mechanical retention of bacteria to the margins of the full veneer crowns, which may cause deleterious effects on gingiva, extending the margins more subgingivally will lead to gingival tissue damage. ${ }^{8}$ The study has been designed to assess the effect of different marginal locations and fabrication place of full veneer crowns on the gingival health on Saudi patients with different educational levels. 
The results of present study showed an increase in gingival index in the area restored with full veneer crown in comparison to the contralateral natural tooth. Higher gingival index will increase the progress of the inflammation of the surrounding gingival tissue especially with subgingival margins. This is in agreement with the observations by Al-Sinaidi, ${ }^{7}$ who showed that the area with the abutment teeth clearly has higher scores in the gingival index than the other area with the nonabutment teeth.

In reference to the crown margin location, the study showed that teeth with the subgingival margin had a significantly higher gingival index than the teeth with equigingival and supragingival margin. Similar results were reported in the literature. ${ }^{2,7-9,11,12,19,21}$

The subgingival margin increases the chance for bacterial retention and provide an environment for bacteria maturation that is difficult to keep clean by the patients. ${ }^{21}$ Therefore, to prevent bacterial retention on the full veneer crowns, the margins should be away from gingiva. ${ }^{22}$ However, Koth ${ }^{23}$ Richter and Ueno ${ }^{24}$ reported that the marginal location of full veneer crown has limited the effect on the periodontal and gingival health in patients who maintain frequent oral home care. As an esthetic requirement, sometimes it is preferred to hide the full veneer crown margin beneath the free gingival margins when it used in the esthetic area. ${ }^{25}$ Furthermore, the presence of subgingival margins in addition to the roughness and opening in the gingival margins, the opportunity of gingival tissue inflammation will increase. Ideal tooth preparation with a good details final impression allowed the technician to fabricate well contoured crown following the original tooth anatomy.

Equigingival margins can be prepared and finished easily, but it is not preferred too because there is a chance of gingival tissue irritation.

Supragingival margins are less likely to have gingival tissue irritation especially when the patients are maintaining a good oral hygiene. Whenever the gingival margins are located supragingivally, impressions could be easily taken, gingival margins will be finished properly and smoothly, and the gingival tissue health will be maintained. ${ }^{26}$ Supragingival margins preferred to be used in nonesthetic areas.

The more pushing the gingival margins below free gingiva, the more biological width violation.

When the violation occurred, it can be treated either surgically or orthodontically. So preserving the health of the gingival tissue is considered vital for the success of any restoration. ${ }^{25}$

Also, our study showed that the educational level of the patients does not affect the gingival health, which is in contradiction with a study by Claire Higgins, who reported that patients with a low educational level have poor general health, which leads to poor oral health. ${ }^{27}$

Full veneer crowns fabricated at private clinics showed a higher gingival index than full veneer crowns fabricated at government clinics; the reason might be that at government clinics, a specialist would do full veneer crowns rather than a general practitioner. Male and female patients have no clear difference on the gingival index.

This study was limited to several factors and the most important factor is the limited availability of time (affecting a number of cases); many parameters such as crown material and toothbrush were not included in the study.

\section{ConcLusion}

Within the limitations of this study, it is concluded that full veneer crowns with the sub-gingival margin has a high gingival index than equigingival and supragingival margins. The full veneer crowns fabricated at governmental clinics have a low gingival index, and there is no positive relationship between the educational level and gingival health around the crowns.

\section{References}

1. Blair FM, Wassell RW, et al. Crowns and other extra-coronal restorations: Preparations for full veneer crowns. Br Dent J 2002 May 25;192(10):561-571. DOI: 10.1038/sj.bdj.4801428.

2. Valderhaug J, Birkeland JM. Periodontal conditions in patients 5 years following insertion of fixed prostheses. Pocket depth and loss of attachment. J Oral Rehabil 1976 Jul;3(3):237-243. DOI: 10.1111/j.13652842.1976.tb00949.x.

3. Kinane DF. Causation and pathogenesis of periodontal disease. Periodontol 2000 2001;25:8-20. DOI: 10.1034/j.16000757.2001.22250102.x.

4. Gracis S, Fradeani M, et al. Biological integration of aesthetic restorations: factors influencing appearance and long-term success. Periodontol 20002001 Oct 1;27(1):29-44. DOI: 10.1034/j.16000757.2001.027001029.x.

5. Herbert TS. Preservation of the periodontium, Fundamentals of Fixed Prosthodontics. 3rd ed. Quintessence Publishing Co; 1997.

6. Karlsen K. Gingival Reactions to Dental Restorations. Acta Odontol Scand 1970 Jan 1;28(6):895-904. DOI: 10.3109/00016357009028253.

7. Al-Sinaidi A, Preethanath RS. The effect of fixed partial dentures on periodontal status of abutment teeth. Saudi J Dent Res 2014;5(2): 104-108. DOI: 10.1016/j.ksujds.2013.11.001.

8. Aboelsaad N, Rayyan MM, et al. An Update on the Effect of Crown Margin Locations and Materials on Periodontal Health. Egypt Dent J 2010 Oct;58(4):91-96.

9. Orkin DA, Reddy J, et al. The relationship of the position of crown margins to gingival health. J Prosthet Dent 1987;57(4):421-424. DOI: 10.1016/0022-3913(87)90006-0.

10. Silness J. Periodontal conditions in patients treated with dental bridges. J Periodontal Res 1970 Feb 1;5(1):60-68. DOI: 10.1111/j.16000765.1970.tb01839.x.

11. Valderhaug J, Ellingsen JE, et al. Oral hygiene, periodontal conditions and carious lesions in patients treated with dental bridges. J Clin Periodontol 1993 Aug 1;20(7):482-489. DOI: 10.1111/j.1600-051X.1993. tb00395.x.

12. Reitemeier $B$, Hänsel $K$, et al. Effect of posterior crown margin placement on gingival health. J Prosthet Dent 2002 Feb 1;87(2): 167-172. DOI: 10.1067/mpr.2002.121585.

13. Ortolan SM, Viskić J, et al. Oral hygiene and gingival health in patients with fixed prosthodontic appliances-a 12-month follow-up. Coll Antropol 2012 Mar;36(1):213-220.

14. Sorensen JA, Doherty FM, et al. Gingival enhancement in fixed prosthodontics. Part I: Clinical findings. J Prosthet Dent 1991 Jan;65(1):100-107. DOI: 10.1016/0022-3913(91)90059-6.

15. Reeves W. Restorative margin placement and periodontal health. J Prosthet Dent 1991; 733-736. DOI: 10.1016/0022-3913(91) 90405-L.

16. Löe H. The Gingival Index, the Plaque Index and the Retention Index Systems. J Periodontol 1967 Nov 1;38(6 Part II):610-606. DOI: 10.1902/ jop.1967.38.6_part2.610.

17. Brijendra S, Ritu S. Gingivitis - A silent disease. Gingivitis - Silent Dis 2013;6(5):30-33.

18. Löe H. Reactions to marginal periodontal tissues to restorative procedures. Int Dent J 1968 Dec;18(4):759-778.

19. Sackett BP, Gildenhuys RR. The Effect of Axial Crown Overcontour on Adolescents. J Periodontol 1976;47(6):320-323. DOI: 10.1902/ jop.1976.47.6.320.

20. Sirajuddin S. latrogenic Damage to Periodontium by Restorative Treatment Procedures: An Overview. Dep Periodontol Rajarajeswari Dent Coll Hosp Bangalore-560074 Karnataka India 9:217-222.

21. Silness J. Periodontal conditions in patients treated with dental bridges. 3. The relationship between the location of the crown margin 
and the periodontal condition. J Periodontal Res 1970;5(3):225-229. DOI: 10.1111/j.1600-0765.1970.tb00721.x.

22. Günay $H$, Seeger $A$, et al. Placement of the preparation line and periodontal health-a prospective 2-year clinical study. Int J Periodontics Restorative Dent 2000 Apr;20(2):171-181.

23. Koth DL. Full crown restorations and gingival inflammation in a controlled population. J Prosthet Dent 1982;48(6):681-685. DOI: 10.1016/S0022-3913(82)80028-0.

24. Richter WA, Ueno $\mathrm{H}$. Relationship of crown margin placement to gingival inflammation. J Prosthet Dent 1973;30(2):156-161. DOI: 10.1016/0022-3913(73)90050-4.
25. Rajendran M. Biologic Width-Critical Zone for a Healthy Restoration. IOSR J Dent Med Sci IOSR-JDMS 2014;1(13):93-98. DOI: 10.9790/085313249398.

26. Sood S, Gupta S. Periodontal-Restorative Interactions: A Review. http://medind.nic.in/iaa/t13/i4/iaat13i4p707.pdf [Internet]. 2013 Apr [cited 2017 Mar 29]; Available from: http://imsear.hellis.org/ handle/123456789/182515.

27. Claire Higgins I of PH in I. Health Impacts of Education: a review [Internet]. 2008 [cited 2017 Mar 25]. Available from: http://www.apho. org.uk/resource/item.aspx?RID $=65160$. 